UDC 615.32

\title{
Curcuma longa AQUEOUS EXTRACT PREVENTS MYOCARDIAL INJURY IN HYPERCHOLESTEROLAEMIC ALBINO RAT
}

\author{
I. B. EKEIGWE, I. C. IKEGWUONU, I. K. UCHENDU ${ }^{\bowtie}$, \\ C. A. UCHENNA, U. C. OKONGWU \\ Department of Medical Laboratory Science, University of Nigeria, Enugu; \\ 凶email: ikenna.uchendu@unn.edu.ng
}

Received: 01 March 2019; Accepted: 17 May 2019

Coronary atherosclerosis is known to be associated with cardiomyopathy in patients worldwide. Presently there is a high prevalence of cardiovascular risk across the globe and the cost of heart disease treating is very high. Therefore, prevention of heart diseases has become the better or easier option. The aim of the present study was to evaluate the cardioprotective effects of Curcuma longa aqueous extract (AECL) in hypercholesterolaemic rats. To achieve this 40 rats were randomly devided into four groups with 10 rats per group. Rats from the group I (normal control) received no treatment. High cholesterol diet $(2 \mathrm{~g} / \mathrm{kg}$, oral) and high dose of anti-thyroid hormone drug carbimazole ( $60 \mathrm{mg} / \mathrm{kg}$, oral) were administered once daily for 8 weeks to induce hypercholesterolaemia in rats of II-IV groups. Group II served as toxic (negative) control and group III (positive control) was treated with a standard lipid-lowering drug atorvastatin (20 $\mathrm{mg} / \mathrm{kg}$, oral). Group IV received AECL $(200 \mathrm{mg} / \mathrm{kg})$ once daily for 8 weeks. For lipid profile analysis the total cholesterol, high density lipoprotein cholesterol, triglycerides levels were estimated and creatine kinase, lactate dehydrogenase and aspartate transminase activities as cardiac biomarkers were assayed in blood serum using standard methods. The histopathological analysis of the heart tissue was carried out. It was shown that AECL significantly reduced hyperlipidaemia, stabilized cardiac biochemical markers and protected the cardiac muscle fibers from injury. The results of the present study suggest that the Curcuma longa extract has cardioprotective potential, and can be used to prevent hypercholesterolaemia-induced myocardial injury.

Ke y wo rd s: ethnopharmacology, carbimazole, atorvastatin, hypercholesterolaemia, cardiomyopathy, cardioprotection, Curcuma longa.

$\mathrm{F}$ or long, coronary heart disease (CHD) has continued to rank as number one cause of death in most Northern European, North American and other developed countries [1]. Atherosclerosis-related cardiovascular diseases are also important. Hypercholesterolaemia and hyperlipidaemia, have long been associated with atherosclerosis [2, 3], and are also known precursors of CHD [4]. Hypercholesterolaemia induces oxidative stress and causes vascular endothelial dysfunction, which may in turn intensify injury of cardiac muscle fibres [5].

Uncontrolled abnormalities in serum lipids levels or dyslipidaemia have been implicated in the onset of CHDs. Lowering lipids and cholesterol levels by drug or dietary interventions could reduce the risk of CHD. Recently, there has been increased interest in research on natural products, with potentials to lower blood cholesterol levels. Many herbal or plant products were reported to have a potential to reduce lipid and cholesterol in the body [2, 6].

Turmeric (Curcuma longa), an annual plant, belongs to the ginger family of herbs, zingiberaceae. Its use in folklore medicine to treat numerous diseases is well documented [7]. Nutrition interacts with organs in the body, in many ways and the possible effect of slowing down organ damage has been considered. Several studies have emphasized on the importance of dietary composition in the treatment of diseases [8].

Hypercholesterolaemic rats have been reported to develop systemic organ complications, including heart injury [6]. Thus investigation into the preven-

(C) 2019 Ekeigwe I. B. et al. This is an open-access article distributed under the terms of the Creative Commons Attribution License, which permits unrestricted use, distribution, and reproduction in any medium, provided the original author and source are credited. 
tion and treatment of abnormal cholesterol levels or heart injury complications, with a simple and common medicinal plant like Curcuma longa, is an important step in maintaining optimum health. To date, there is no literature on the effects of Turmeric against hypercholesterolaemia-induced cardiomyopathy. The aim of this research was to evaluate the cardioprotective effects of aqueous extract of Curcuma longa in hypercholesterolaemic rats.

\section{Materials and Methods}

Turmeric. Fresh samples of Curcuma longa were obtained from local market in Enugu, Nigeria. The plant material was authenticated by a consultant taxonomist at the herbarium section of the Department of Plant Science and Biotechnology, University of Nigeria, Nsukka, and a voucher specimen was deposited at the herbarium with reference number [UNH $205^{\mathrm{C}}$ ] for future reference.

Aqueous extract of Curcuma longa (AECL). Preparation as described by Uchendu and Agu [9] was done, with slight modification. Briefly, hot-water extraction of powdered turmeric was prepared by boiling $100 \mathrm{gm}$ in $1000 \mathrm{ml}$ distilled water over low flame for $15 \mathrm{~min}$, using a heat-stable flask. The content of the flask was allowed to cool for $20 \mathrm{~min}$. After cooling, the supernatant of the mixture was filtered through a Whatman filter (Whatman Clifton, NJ, USA). The filtrate was used to prepare the required concentration.

Acute toxicity test $\left(L D_{50}\right)$. This was performed on mice and Lorke [10] procedure of $\mathrm{LD}_{50}$ determination was used.

Phytochemical analysis of turmeric. Preliminary phytochemical screening of Curcuma longa was carried out at Department of Pharmacognosy, Faculty of Pharmaceutical Science, University of Nigeria Nsukka. Procedures outlined by Trease and Evans [11] were employed for the analyses.

Experimental animals. Forty albino Wistar rats were used for the research. They were obtained from the animal house at Anatomy Department, University of Nigeria, Enugu campus. The rats were divided into 4 groups. Groups: I, II, III and IV, 10 rats per group according to their body weights (200 \pm 20 g). The animals were housed in clean steel-gauzed cages, under standard condition $28 \pm 3{ }^{\circ} \mathrm{C}$ and a $12 \mathrm{~h}$ light/12 h dark cycle at the animal house at Anatomy department, College of medicine, University of Nigeria, Enugu Campus. They were allowed to acclimatize for a period of 2 weeks, with regular clinical examination, before the experiment. The experimental protocol was approved by the Institution animal ethics committee of the University of Nigeria Teaching Hospital (UNTH/CSA. 1005/VOL. 18).

Reagents. Total cholesterol (TC) kit, HDL cholesterol kit, triglyceride kit and AST assay kit were purchased from Randox Laboratory (UK); CKMB ELISA kit purchased from Elabscience (Texas, USA); LDH ELISA kit was purchased from MyBioscience (San Diego, USA), carbimazole (CBM) from Hovid Inc (Malaysia), atorvastatin (ATOR) obtained from pfizer Inc. (New York, USA). All other reagents were obtained from local suppliers (Enugu, Nigeria) and were of analytical grade.

High-cholesterol diet (HCD). A mixture of $75 \mathrm{~g}$ of commercially available cholesterol powder and $9 \mathrm{~g}$ of sodium deoxycholate (bile salt added to increase bioavailability) was dissolved in coconut oil and made up with the same solvent to $300 \mathrm{ml}$ to give a stock concentration of $250 \mathrm{mg} / \mathrm{ml}$.

Solutions. 100 tablets of $5 \mathrm{mg}$ (i.e. $500 \mathrm{mg}$ ) carbimazole were ground to powder, dissolved in distilled water and made up to $250 \mathrm{ml}$ in a measuring cylinder to give a stock concentration of $2 \mathrm{mg} / \mathrm{ml}$ of carbimazole solution. Atorvastatin (10 tablets of $10 \mathrm{mg}$ ) were ground to powder, dissolved in distilled water and made up to $50 \mathrm{ml}$ mark in a volumetric flask to give a stock concentration of $2 \mathrm{mg} / \mathrm{ml}$ of atorvastatin solution.

Induction of hyperlipidaemia and cardiac inju$r y$. Each experimental rat was co-administered with high cholesterol diet (HCD) at the dose of $2 \mathrm{~g} / \mathrm{kg}$ and high dose of $60 \mathrm{mg} / \mathrm{kg}$ carbimazole solution through an oral gauge every morning for eight weeks.

Experimental design. The rats were divided into 4 groups. Group I served as the normal control; therefore received no treatment. Group II received HCD (2 g/kg, oral), carbimazole (60 mg/kg, oral), with neither extract nor drug for 8 weeks. This served as the toxic (negative) control. Group III received HCD, carbimazole and atorvastatin $(20 \mathrm{mg} /$ $\mathrm{kg}$, oral) for 8 weeks. This served as positive control group. Group IV received HCD, carbimazole and

\footnotetext{
Abbreviation: AECL - aqueous extract of Curcuma longa; ATOR - atorvastatin, TC - total cholesterol; HDL-C - high density lipoprotein cholesterol; TG - triglycerides; CK - creatine kinase; LDH - lactate dehydrogenase; AST - aspartate transaminase; CHD - coronary heart disease; CBM - carbimazole; HCD - high cholesterol diet.
} 
AECL (200 mg/kg, oral). This served as treatment group.

Blood Sample. After 8 weeks, $6 \mathrm{ml}$ of blood was collected from the axillary vein under chloroform anesthesia, after at least a $12 \mathrm{~h}$ overnight fast. The blood was dispensed into a plain container, allowed to clot at room temperature, spun at 5,000 r.p.m for 5 min; serum was separated and cryopreserved for analysis of fasting lipid profile (TC, HDL cholesterol and triglyceride), and cardiac biomarkers (CK-MB, LDH and AST). The hearts were harvested for histopathological studies.

Biochemical analysis. Measurement of serum lipid profile. TC was estimated using cholesterol oxidase method [12], HDL-C was determined using precipitation method [13] and triglyceride (TG) was estimated using glycerol phosphate oxidase method [14].

Measurement of cardiac biomarkers. The serum activities of the creatine kinase isoenzyme, CK$\mathrm{MB}$ and LDH were determined using enzyme immunoassay (kit) method [15]. AST was determined using colorimetric method [16].

Histopathological analysis. The excised hearts were processed using the paraffin wax embedding technique, and sectioned at $5 \mu \mathrm{m}$. The tissue was stained using haematoxylin and eosin [17], and examined using an Olympus ${ }^{\mathrm{TM}}$ light microscope.

Statistical analysis. Data analysis was done using GraphPad prism version 6.0 (GraphPad, San Diego, CA, USA). The results of the biochemical assays were reported as mean \pm SEM (standard error of mean). Data significance was tested using one way analysis of variance (ANOVA). Results were assumed significant at $P<0.05$.

\section{Results and Discussion}

Acute toxicity studies. $\mathrm{LD}_{50}$ value of the extract was $7.5 \mathrm{~g} / \mathrm{kg}$ which indicates that AECL is safe and is not toxic to mice

Phytochemical results. The result of the preliminary phytochemical analysis of Curcuma longa revealed moderate presence of flavoniods, phenolic compound and terpenoid (++); and presence (in trace amount) of alkaloids, glycosides, phytosterols, saponnins and tannins (+). However carbohydrates, reducing sugar, resins, proteins and oils were absent (Table 1).

Table 2 shows the results of serum lipid profile parameters: TC, HDL and TG levels in the different experimental. From the results, AECL showed sig- nificant antihyperlipidaemic potentials $(P<0.05)$ in comparison with negative control (HCD+CBM). Furthermore, it was observed that the standard drug (atorvastatin) showed much better antihyperlipidaemic effects in the rats than the extract.

In Fig. $1(A-C)$, rats which received (HCD + $\mathrm{CBM}$ ) alone (negative control) for 8 weeks showed the highest serum CK-MB, LDH and AST levels. Data show that coadministration of high cholesterol diet and high dose carbimazole for 8 weeks induced a significant increase in the level of serum CK-MB, LDH and AST in the rats $(P<0.01$ or $P<0.05)$ in comparison with normal control. The positive control, atorvastatin, a standard lipid-lowering drug was shown to induce a significant decrease in CK$\mathrm{MB}, \mathrm{LDH}$ and AST levels in the rats compared with (HCD+CBM) alone $(P<0.01$ or $P<0.05)$. Interestingly, AECL also significantly decreased CKMB, LDH and AST levels when compared with (HCD+CBM) alone $(P<0.01$ or $P<0.05)$.

Histopathological results. The results are represented in Fig. 2 (I-IV). Microscopic examination of the hearts revealed no histopathological alteration in the normal control rats (Fig. 2, I). Presence of significant distortion and necrosis of the myocardial fibres were observed in the heart of rats treated with oral administration of high cholesterol diet and high dose carbimazole (Fig. 2, II); however non-significant degenerations were observed in rats administered with

Table 1. Qualitative phytochemical results of aqueous extract of Curcuma longa

\begin{tabular}{l|c}
\hline \multicolumn{1}{c}{ Constituent } & Indication \\
\hline Carbohydrate & - \\
Reducing sugar & - \\
Alkaloids & + \\
Glycosides & + \\
Saponins & + \\
Tannins & + \\
Flavonoids & ++ \\
Resins & - \\
Proteins & - \\
Oils & - \\
Phenolic compounds & ++ \\
Terpenoids & ++ \\
Phytosterols & + \\
\hline
\end{tabular}

Key: $++=$ present; $+=$ present (in trace amount); $-=$ absent 
Table 2. Comparison of serum lipid profile of treated groups with negative controls

\begin{tabular}{l|c|c|c}
\hline \multicolumn{1}{c|}{ Groups } & Serum TC, mmol/l & Serum HDL-C, mmol/l & Serum TG, mmol/l \\
\hline Normal control & $4.980 \pm 0.126^{*}$ & $2.359 \pm 0.091^{*}$ & $1.389 \pm 0.038^{*}$ \\
HCD+CBM (Negative control) & $6.021 \pm 0.329$ & $1.301 \pm 0.091$ & $2.520 \pm 0.294$ \\
HCD+CBM+ATOR (Positive control) & $5.063 \pm 0.075^{* *}$ & $2.349 \pm 0.111^{*}$ & $1.381 \pm 0.052^{*}$ \\
HCD+CBM+AECL (Test) & $5.428 \pm 0.287^{*}$ & $2.256 \pm 0.120^{*}$ & $1.649 \pm 0.029$ \\
\hline
\end{tabular}

Values given as mean \pm SEM. ${ }^{* *} P<0.01$ or $* P<0.05$ is significant when $(\mathrm{HCD}+\mathrm{CBM})$ is compared with all other groups

atorvastatin (20 mg/kg) and AECL (200 mg/kg) separately (Fig. 2, III and 2, IV respectively). The hearts of rats in group III and IV showed no significant histological alterations when compared with the normal control group.

In hypercholesterolaemia-induced organ or tissue model, cholesterol aggravates stress-mediated apoptosis [18]. Carbimazole (an anti-thyroid hormone drug) has been extensively reported to have toxic effects on delicate organs, such as the testes and other tissues [19-22]. Furthermore, hypothyroidism alters antioxidant defense system in rat [20, 23]. Based on this scientific evidence, a high dose of carbimazole (60 mg/kg, oral), was administered to the rats, for 8 weeks.

Thyroid hormone plays an important role in the regulation of lipid metabolism. Hypothyroidism has been implicated as the cause of hypercholesterolaemia in hypothyroid patients [24]. Thus carbimazole was used in the study to cause a thyroid hormone deficiency which enabled rapid onset of hypercholesterolaemia in the experimental rats.

Aside inducing hypercholesterolaemia, its cardiotoxic mechanism is not well understood. Although the mechanism of testicular injury by carbimazole has been extensively reported to be due to increase in oxidative stress, possibly the coadministration of HCD and the high dose carbimazole to the rats for 8 weeks synergistically induced the chronic cardiac muscle effects, observed in this study. Therefore, the cardiac muscle changes could be explained on the basis of increased oxidative stress.

In the last few decades, there has been the growing use of herbal medicines because most plants are believed to have medicinal value, turmeric being one of them. The aim of this study was to evaluate the antidyslipidaemic and cardioprotective effects of aqueous extract of Curcuma longa in hypercholesterolaemic rats; using atorvastatin as a reference drug. This present study has shown that AECL prevented dyslipidaemia and cardiomyopathy after the 8 weeks treatment period. Treatment with atorvastatin induced significant antidyslipidaemic effect and cardiac protection. The histopathological results showed concomitant association with the biochemical results.

The effects observed in this study could be due to the singular or combined effects of the bioactive phytochemicals present in turmeric extracts, particularly saponins and phytosterols (Table 1). The hypocholesterolaemic effects of saponins have long been recognized [25]. Two mechanisms by which saponins can affect cholesterol metabolism were suggested [26]. 1) Some saponins with particularly defined structural characteristics form insoluble complexes with cholesterol. When this complex-forming process occurs in the gut, it inhibits intestinal absorption of both endogenous and exogenous cholesterol. 2) Saponins can interfere with the entero-hepatic circulation of bile acids by forming mixed micelles. The re-absorption of bile acids from the terminal ileum is effectively blocked [27]. In animal models, soya saponins were found to significantly reduce serum TC, low-density lipoprotein-cholesterol (LDLC), TG concentrations, and to increase high-density lipoprotein-cholesterol (HDL-C) levels in rats [28]. Phytosterols that have long been known to reduce intestinal cholesterol absorption, lead to decrease blood LDL-cholesterol levels and lower cardiovascular disease risk. In the 1950's, phytosterols from soybeans were found to lower serum cholesterol level [29]. Since then, the cholesterol-lowering effects of phytosterols have been extensively demon strated in both humans and animals [30].

Hyperlipidaemia and oxidative stress following the hypercholesterolaemic diet could be prevented by endogenous and exogenous antioxidants [31]. The protection by artovastatin as observed in the present study may be due to the anti-inflammatory and antioxidant properties of atorvastatin, which has been reported to have a potential protective effect on kidney function [32]. 


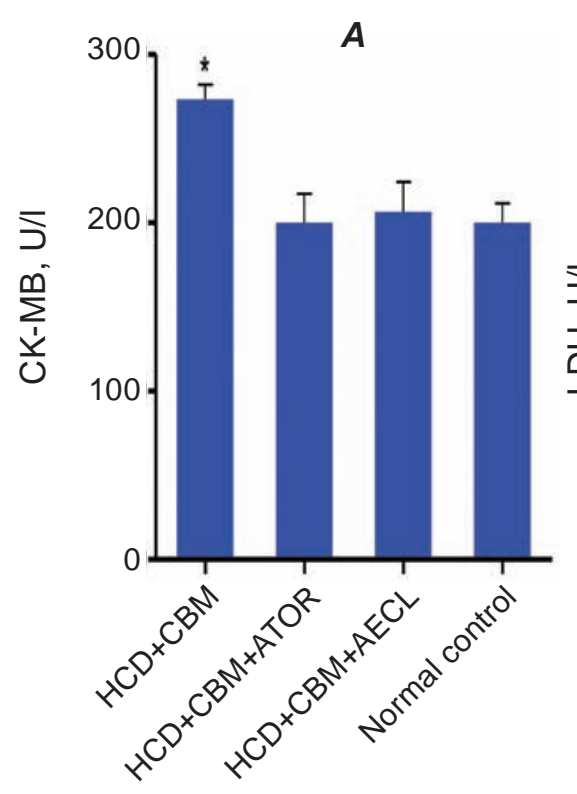

Treatment groups

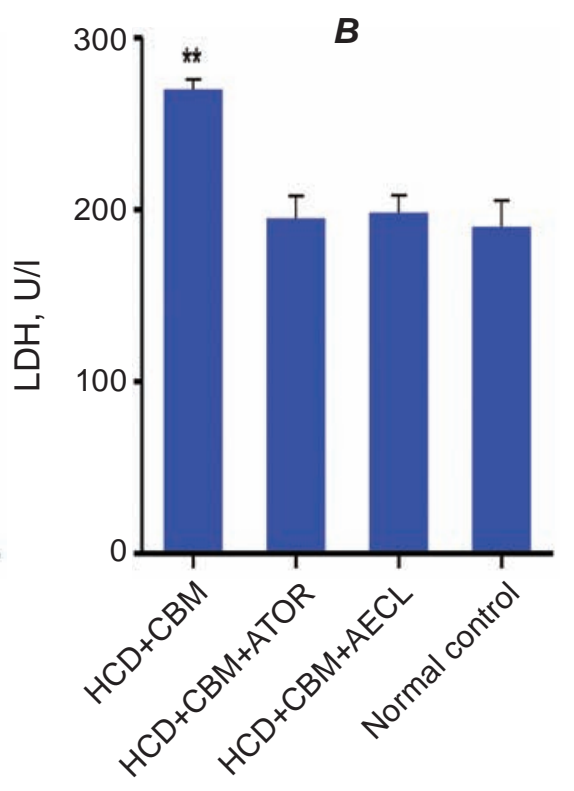

Treatment groups

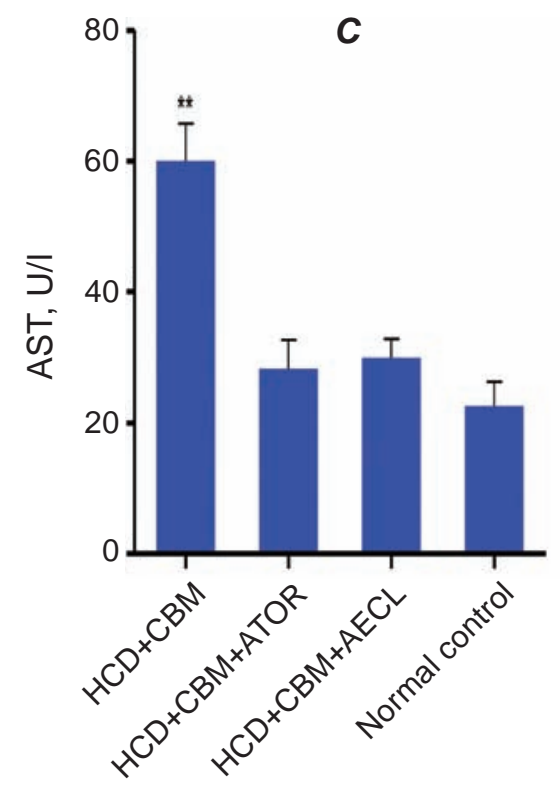

Treatment groups

Fig. 1. Cardiac biochemical markers. Following treatment with atorvastatin (ATOR) or aqueous extract of Curcuma longa (AECL), serum levels of $C K-M B, L D H$ and $A S T$ ( $A, B$, and $C$, respectively) were significantly decreased when compared with negative control. The data are presented as mean \pm SEM of serum CK-MB, $L D H$ and AST levels (U/L) for individual treatment. HCD+CBM (negative control) - rats with experimentally induced hypercholesterolaemia; $H C D+C B M+A T O R$ - rats treated with the standard lipid-lowering drug atorvastatin; $H C D+C B M+A E C L$ - rats treated with AECL; Normal control - rats without any treatment; statistical analyses were performed using ANOVA (**P $<0.01$ or $* P<0.05), n=10$

Recently, the role of diet in human health has received considerable attention. Several epidemiological studies have indicated that a high intake of plant products is associated with a reduced risk of a number of chronic diseases, such as atherosclerosis and cancer [33]. The consumption of plant products was shown to reduce hypercholesterolaemia, oxidative stress, homocystienaemia, endothelia dysfunction and blood pressure $[34,35]$. These beneficial effects have been partly attributed to the compound which possesses antioxidation. Tumeric is rich in both anti-inflammatory and antioxidant phytochemicals such flavonoids.

The implication of this study is that turmeric is cardioprotective and its consumption should be encouraged in families. Further research on effects of different extracts of turmeric should be evaluated for more potential health benefits. Food and drug industries should harness the protective property of turmeric for the general benefit of mankind. Attention should be focused on the cardioprotective effects of turmeric against coronary heart disease.
This study showed that the aqueous extract of Curcuma longa has effect on the lipid metabolism and prevents cardiomyopathy in albino rats fed a high cholesterol diet and high dose carbimazole. Therefore, the alterations in the serum lipid by the aqueous extract of Curcuma longa may not predispose the heart to atherosclerosis or its associated cardiomyopathy or infarction.

Acknowledgement. The author expresses deep sense of gratitude to Mr. Chris Ireoba, The head of department of the Laboratory Division at Eastern Nigeria Medical Centre, Enugu, and all the technical staff for their kind cooperation.

Conflict of interest. Authors have completed the Unified Conflicts of Interest form at http:// ukrbiochemjournal.org/wp-content/uploads/2018/12/ coi_disclosure.pdf and declare no conflict of interest.

Funding. This research did not receive any specific grant from any funding agency. 

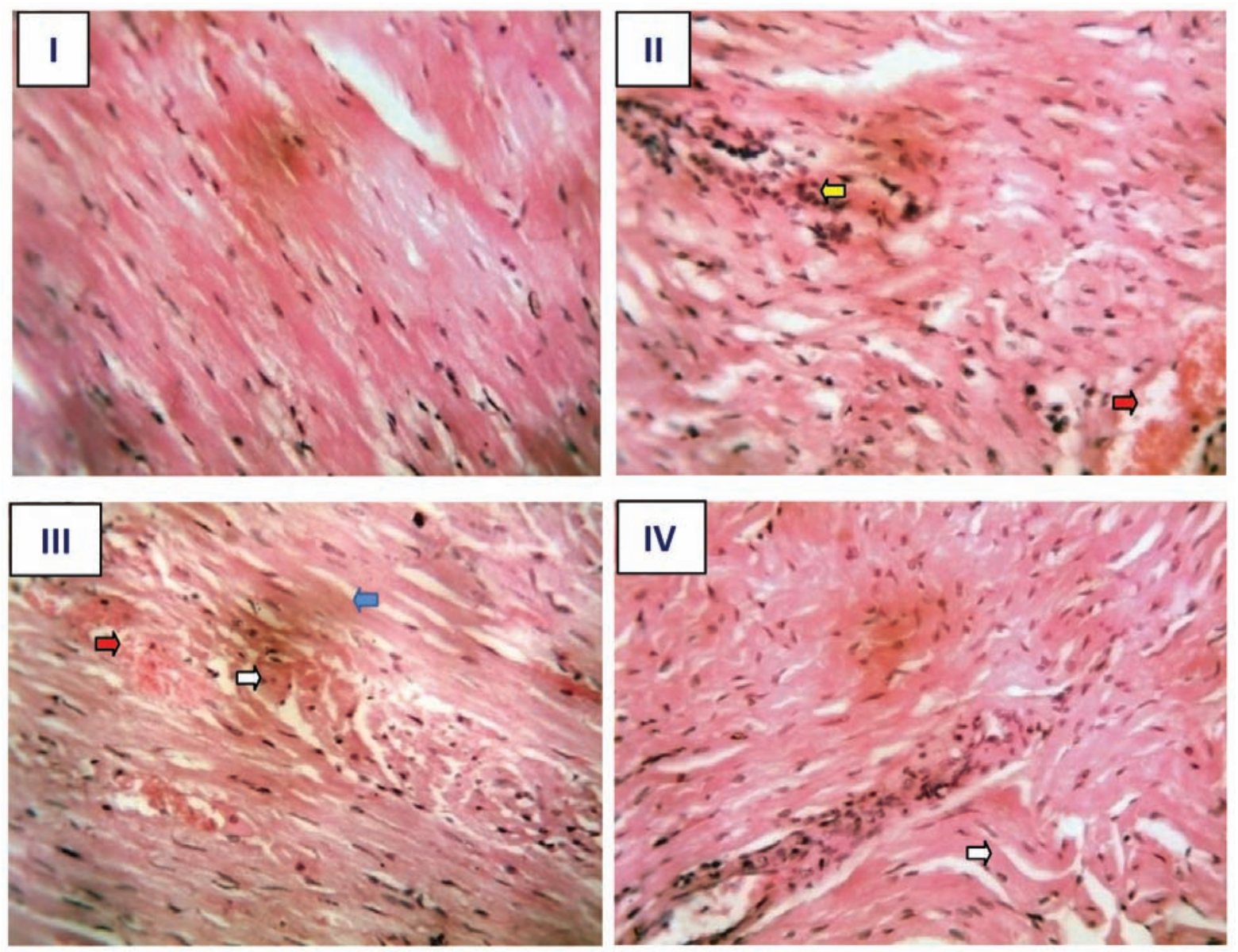

Fig. 2. Photomicrograph of heart. (I) No pathological lesions in the myocardial fibres. (II) Presence of significant distortion of the myocardial fibres; necrosis with infiltration by leucocytes (yellow arrow) is seen in some. Severe congestion of the blood vessel is also present (red arrow). (III) Myocardial fibres are normal - longitudinal (blue arrow) and oblique sections (white arrow) appear normal. The blood vessels seen are mildly congested. (IV) Myocardial fibres appear wavy (white arrow); some fibres are necrotic with infiltration by leucocytes. [Stain: haematoxylin and eosin; $\times 400]$

\section{ВОДНИЙ ЕКСТРАКТ CURсUта longa ЗАПОБІГАЕ ЗМІНАМ БIОХIМIЧНИХ МАРКЕРІВ СЕРЦЕВИХ УШКОДЖЕНЬ У ЩУ РІВ-АЛЬБІНОСІВ ІЗ ГІПЕРХОЛЕСТЕРИНЕМІЄЮ}

\section{B. Ekeigwe, I. C. Ikegwuonu, \\ I. K. Uchendu ${ }^{\varpi}$, C. A. Uchenna, U. C. Okongwu \\ Department of Medical Laboratory Science, University of Nigeria, Enugu; 凶email: ikenna.uchendu@unn.edu.ng}

Коронарний атеросклероз асоціюється 3 кардіоміопатією в пацієнтів у всьому світі. Piвень серцево-судинних ризиків дуже високий в усьому світі, а лікування серцевих захворювань стає величезним фінансовим тягарем, тому профілактика серцевих захворювань $є$ кращою та ефективною опцією. Метою дослідження було оцінити кардіопротекторну дію водного екстракту Curcuma longa (AECL) в щурів із гіперхолестеринемією. В експерименті використовували 40 щурів, випадковим чином розділених на чотири групи (I, II, III, IV) - по 10 щурів в кожній групі. Група I (нормальний контроль) не отримувала ніякого лікування. Групи II-IV отримували дієту з високим вмістом холестеролу (2000 мг/кг, перорально) і високу дозу карбімазолу (60 мг/кг, перорально) один раз на день протягом 8 тижнів для індукції гіперхолестеринемії. Група II служила токсичним (негативним) контролем. Група III (позитивний контроль) отримувала лі- 
кування аторвастатином (20 мг/кг, перорально). Група IV (група лікування) отримувала AECL (200 мг/кг) один раз на день протягом 8 тижнів. Біохімічний аналіз проводили стандартними методами. Визначали такі біохімічні показники: параметри ліпідного профілю (загальний холестерол, холестерол ліпопротеїнів високої щільності, тригліцероли) і біомаркери серця (активність креатинкінази, лактатдегідрогенази i аспартат трансамінази). Серця було використано для гістопатологічних досліджень. Показано, що AECL сприяє гіполіпідемії, стабілізує біохімічні маркери серця $(P<0,05$ або $P<0,01)$; захищає волокна серцевих м'язів від ушкоджень. Одержані результати дозволяють припустити, що екстракт Curcuma longa має кардіопротекторний потенціал і може бути використаний для запобігання ушкодження міокарда, спричиненого гіперхолестеринемією.

К люч ч в і с лов а: етнофармакологія, карбімазол, гіперхолестеринемія, кардіоміопатія, кардіопротекція, Curcuma longa.

\section{References}

1. Lamprea-Montealegre JA, McClelland RL, Grams M, Ouyang P, Szklo M, de Boer IH. Coronary heart disease risk associated with the dyslipidaemia of chronic kidney disease. Heart. 2018; 104(17): 1455-1460.

2. Kingsley UI, Steven OO, Agu CE, Orji OC, Chekwube BE, Nwosu TF. Anti-hyperlipidemic effect of crude methanolic extracts of Glycine max (soy bean) on high cholesterol diet-fed albino rats. J Med Allied Sci. 2017; 7(1): 34-40.

3. Smith GD, Shipley MJ, Marmot MG, Rose G. Plasma cholesterol concentration and mortality. The Whitehall Study. JAMA. 1992; 267(1): 7076.

4. Muntner PM, Corsh J, Klag MJ, Smith JC, Eckfelvt J. Lipids and incipient hypercreatinaemia: A prospective association. J Am Sociol Neophrol. 1998; 9: 617.

5. Araya J, Rodrigo R, Orellana M, Rivera G. Red wine raises plasma HDL and preserves longchain polyunsaturated fatty acids in rat kidney and erythrocytes. Br J Nutr. 2001;86(2):189-95.

6. Ikenna KU, Okechukwu SO, Chidozie EA, Oliver CO, Blessing EC, Tochi FN. Hypolipidaemic and renoprotective effects of Glycine max (Soy bean) against lipid profile and renal biochemical alterations in hypercholesterolemic rat. Int $\mathrm{J}$ Biomed Res. 2016; 7(12): 822-828.

7. Hewlings SJ, Kalman DS. Curcumin: A review of its' effects on human health. Foods. 2017; 6(10). pii: E92.

8. Uchendu IK, Nnedu EB, Orji OC. Combination of aqueous extracts of Curcuma longa (turmeric) and some calcium channel blockers synergistically improves $\mathrm{CCl}_{4}$ induced hepatotoxicity in albino rats. Pharmacologyonline. 2018; 3: 392-401.

9. Uchendu IK, Agu CE. Anti-nephrotoxic and anti-hyperlipidaemic potentials of aqueous extracts of turmeric (Curcuma longa) in hypercholesterolaemic albino rat. Pharmacologyonline. 2018; 3: 1-11.

10. Lorke D. A new approach to practical acute toxicity testing. Arch Toxicol. 1983; 54(4): 275287.

11. Trease G, Evans SM. Pharmacognosy: (15th Edition). English Language Book Society. Bailliere Tindall, London, 2002. P. 23-67.

12. Fredrickson DS, Levy RI, Lees RS. Fat transport in lipoproteins - an integrated approach to mechanisms and disorders. N Engl J Med. 1967; 276(5): 273-281.

13. Albers JJ, Warnick GR, Chenng MC. Quantitation of high density lipoproteins. Lipids. 1978; 13(12): 926-932.

14. Fossati P, Prencipe L. Serum triglycerides determined colorimetrically with an enzyme that produces hydrogen peroxide. Clin Chem. 1982; 28(10): 2077-2080.

15. Tietz NW. Clinical Guide to Laboratory Tests, $3^{\text {rd }}$ edition W. B. Saunders, co, Philadelphia, 1995; 216-217.

16. Reitman S, Frankel S. A colorimetric method for the determination of serum glutamic oxalacetic and glutamic pyruvic transaminases. Am J Clin Pathol. 1957; 28(1): 56-63.

17. Baker FJ, Silverton RE, Pallister CJ. Baker and Silverton's Introduction to Laboratory Technology. 7th Editon, ButterworthHeinemann, Wobrun, MA, USA, ISBN-13: 978075621908, 1998; 448 p.

18. Wu N, Zhang X, Jia P, Jia D. Hypercholesterolemia aggravates myocardial ischemia reperfusion injury via activating endoplasmic reticulum stress-mediated apoptosis. Exp Mol Pathol. 2015; 99(3): 449-454. 
19. Sakr SA, Mahran HA, Nofal AE. Effect of selenium on carbimazole-induced testicular damage and oxidative stress in albino rats. $J$ Trace Elem Med Biol. 2011; 25(1): 59-66.

20. Sakr SA, Mahran HA, Nofal AE. Effect of selenium on carbimazole-induced histopathological and histochemical alterations in prostate of albino rats. Am J Med Med Sci. 2012; 2(1): 5-11.

21. Sakr SA, EL-Naby SEH, Okdah YA, ElShabka AM. Impact of ginger aqueous extract on carbimazole induced testicular degenerative alterations and oxidative stress in albino rats. J Coastal Life Med. 2017; 5(4): 167-173.

22. Orji OC, Uchendu IK, Agu CE, Nnedu EB, Okerreke AN, Orji GC. Combined Effects of Vitamin C and Tomato Extract (Lycopersicon Esculentum) on Carbimazole-induced Alterations in the Testes of Male Albino Rats. Indian J Physiol Pharmacol. 2018; 62(3): 380384.

23. Jena S, Bhanja S. Hypothyroidism alters antioxidant defence system in rat brainstem during postnatal development and adulthood. Neurol Sci. 2014; 35(8): 1269-1274.

24. Chandurkar V, Shik J, Randell E. Exacerbation of underlying hypothyroidism caused by proteinuria and induction of urinary thyroxine loss: case report and subsequent investigation. Endocr Pract. 2008; 14(1): 97-103.

25. Oakenfull DG, Topping DL. Saponins and plasma cholesterol. Atherosclerosis. 1983; 48(3): 301-303.
26. Oakenfull D. Soy protein, saponins and plasma cholesterol. J Nutr. 2001; 131(11): 2971-2972.

27. Oakenfull D, Sidhu GS. Could saponins be a useful treatment for hypercholesterolaemia? Eur J Clin Nutr. 1990; 44(1): 79-88.

28. Xiao JX, Peng GH, Zhang SH. Prevention effects of soyasaponins on hyperlipidemia mice and its molecular mechanism. Acta Nutrimenta Sinica. 2005; 27: 147-150.

29. Peterson DW. Plant sterols and tissue cholesterol levels. Am J Clin Nutr. 1958; 6(6): 644-649.

30. Moghadasian MH, Frohlich JJ. Effects of dietary phytosterols on cholesterol metabolism and atherosclerosis: clinical and experimental evidence. Am J Med. 1999; 107(6): 588-594.

31. Modaresi A, Nafar M, Sahraei Z. Oxidative stress in chronic kidney disease. Iran J Kidney Dis. 2015; 9(3): 165-179.

32. Verdoodt A, Honore PM, Jacobs R, De Waele E, Van Gorp V, De Regt J, Spapen HD. Do statins induce or protect from acute kidney injury and chronic kidney disease: an update review in 2018. J Transl Int Med. 2018; 6(1): 21-25.

33. Podsędek A. Natural antioxidants and antioxidant capacity of Brassica vegetables: A review. LWT Food Sci Technol. 2007; 40(1): 1-11.

34. Silaste ML, Rantala M, Alfthan G, Aro A, Kesäniemi YA. Plasma homocysteine concentration is decreased by dietary intervention. $\mathrm{Br} J$ Nutr. 2003; 89(3): 295-301.

35. Chopra M, Gu GG, Singh S. Mutations affecting the delayed rectifier potassium current in Drosophila. J Neurogenet. 2000; 14(2): 107-123. 